\title{
The Impact of Firm Specific Factors on the Stock Prices: Empirical Evidence from Belgrade Stock Exchange
}

\author{
Article history: \\ Received: 6 October 2017 \\ Sent for revision: 23 November 2017 \\ Received in revised form: 5 May 2018 \\ Accepted: 7 May 2018 \\ Available online: 29 June 2018
}

\begin{abstract}
This study aims to examine the impact of certain determinants of stock prices on the capital market in development, with a special focus on companies in the Financial and Insurance Activities Sector whose shares are listed on the Belgrade Stock Exchange. The study uses data from individual companies from 2008 to 2014 and employed ordinary least squares method. Generally speaking, the study found that accounting information, in particular, return on assets, book value per share, trust rate and company size measured by market capitalization, are relevant for explaining the stocks prices in Serbia. This study contributes to the current discussion of specific factors affecting the price of stocks in the emerging market with a special focus on the Belgrade Stock Exchange. Cluster analysis of companies according to key determinants of share prices suggests to investors that there is the possibility of portfolio diversification. The reliability in the study is ensured by including nearly $95 \%$ of the companies listed on the Belgrade Stock Exchange, ie shares of companies classified in K - Financial and Insurance Activities Sector on the Belgrade Stock Exchange.
\end{abstract}

Keywords: Financial performances, Stock Prices, Financial and Insurance Activities Sector, Belgrade Stock Exchange

\footnotetext{
${ }^{1}$ University of Novi Sad, Faculty of Economics, Subotica, smilosevic@ef.uns.ac.rs 
Milošević-Avdalović S.: The Impact of Firm Specific Factors on the Stock Prices...

\section{Uticaj specifičnih faktora preduzeća na cene akcija: Empirijski dokazi sa Beogradske berze}

Apstrakt: Ova studija ima za cilj da ispita uticaj određenih determinant cena akcija na tržištu kapitala u razvoju sa posebnim osvrtom na firme iz sektora finansijske delatnosti I delatnost osiguranja listirane na Beogradskoj berzi. Studija koristi podatake pojedinačnih kompanija od 2008. do 2014. godine I koristi metod višestruke regresione analize. Uopšteno govoreći, studija je utvrdila da su računovodstvene informacije, posebno, prinos na aktivu, knjigovodstvena vrednost po akciji, stopa poverenja I veličina preduzeća merena tržišnom kapitalizacijom, relevantne u objašnjavanju cena akcija u Srbiji. Ova studija doprinosi aktuelnoj raspravi o specifičnim faktorima koji utiču na cenu akcija na tržištu u razvoju sa posebnim osvrtom na Beogradsku berzu. Klasterska analiza preduzeća po ključnim determinantama cena akcija sprovedena je da ukaže investitorima na mogućnost diverzifikacije portfolio putem modeliranja. Rezultati se mogu smatrati pouzdanim, jer je obuhvaćeno gotovo 95\% kompanija, koje su listirane na Beogradskoj berzi, odnosno, akcija preduzeća klasifikovana u sektor K - Finansijske delatnosti I delatnos tosiguranja na Beogradskoj berzi.

Ključne reči: Finansijske performanse, cena akcija, sektor Finansijske delatnosti i delatnost osiguranja, Beogradska berza.

\section{Introduction}

The capital market in Serbia is at an early stage of development, but it represents an opportunity for individual investors to achieve high capital gains. Emerging markets are considered to be volatile and risky, but also lucrative capital markets. In developing countries, such as Serbia, stock markets can stimulate economic growth by ensuring that companies increase capital at lower prices. In addition, emerging capital markets depend primarily on financing from bank loans, which increases credit risk. Therefore, there is a huge importance, but also a need for the study and development of capital markets in order to strengthen alternative sources of financing. Factors that affect stock prices are numerous and inexhaustible. The research aims to examine the key internal determinants of the company and their impact on the prices of shares of companies listed on the Belgrade Stock Exchange. Such findings represent a strategic analysis that helps analysts in predicting future value of the company. This implies that investors will be able to make wise investment decisions if they consider these determinants which have emerged as the significant contributors to the market price of shares in Serbia. 
Milošević-Avdalović S.: The Impact of Firm Specific Factors on the Stock Prices...

It is concluded that each sector should have its own model that explains the variation in stock prices. It is important for investors to carefully consider and understand the sectors, as well as how these sectors react to changes in accounting indicators when investing in the stock market.

\section{Literature review}

Plenty of published studies deal with the relationship between financial statements data and the stock market. There are at least four reasons why there is a huge demand for capital markets research in Accounting and for the popularity of these research: (i) fundamental analysis and valuation; (ii) capital market efficiency tests; (iii) role of accounting in making contracts and in the political process; and (iv) disclosure regulation (Kothari, 2001).

In their study, Aveh, Awunyo-Vitor and McMillan (2017) applied the panel regression analysis to examine all companies listed on the Ghana Stock Exchange from 2008 to 2014. In general, the author came up with the conclusion that accounting data, specifically earning per share, return on equity, book value and market capitalization of the firms, are applicable in describing stock prices in Ghana.

Mirza, Rahat \& Reddy (2016) examined the propositions on leverage pricing in returns on stock by analyzing an extensive set of companies listed on the Karachi Stock Exchange (KSE) over a period of 13 years. They pointed out that although size, value and, more importantly, financial leverage are systematic in nature, market risk premium can not be considered as a related factor.

Issah and Ngmenipuo (2015) have found a positive linear relationship between ROA, ROE, ROI and the market price of shares of banking financial institutions quoted on the Ghana Stock Exchange (GSE). Furthermore, the positive signs acquired for the independent variable coefficients are in line with the theoretical framework.

Sharif, Purohit and Pillai (2015) analyzed the essential factors influencing share prices in the Bahrain financial market. The study involved a panel data set of 41 companies registered on the Bahrain stock market from 2006 to 2010.The results indicated that the variables return on equity, book value per share, dividend per share, dividend yield, price earnings ratio, and firm size are important share prices determinants on the Bahrain market.

Almumani (2014) identify the quantitative factors that influence share prices for the listed banks in Amman Stock Exchange over the period 2005-2011. Appertaining to the empirical results, the variables earning per share, book value per share, price earnings ratio, and size are significant determinants of 
Milošević-Avdalović S.: The Impact of Firm Specific Factors on the Stock Prices...

share prices for all the banks under consideration. Thus, in his study, the author succeeds to prove that the study of financial factors is highly beneficial for the investors in Jordan, as these factors bear strong explanatory power and hence, can be used to make authentic predictors of future stock prices.

Chughta, Azeem and Ali (2014) were interested into the relation between chosen companies' distinctive factors and stock prices. As per the analysis, dividend per share and earning per share are found to have a positive and significant effect on share prices of companies. On the other hand, capital investment and retained earnings are found to have no significant consequence on stock prices. It indicates that stock prices are not affected to changes in these two variables.

Numerous studies in different capital markets and different observation times give various results. Although there are key factors that affect stock prices in most countries, generalization of results is not possible due to differences in business environment, business regulations, political situation and the number and type of investors. It can be concluded that the existing literature advocates the belief that the stock price change is due to certain internal aspects of the company.

\section{Research methodology}

\subsection{Data}

In order to examine the hypothesis, the research made use of secondary data. The sample was formed on the basis of companies listed on the Belgrade Stock Exchange. The annual data and a sample of 19 companies from the sector K-Financial and Insurance Activities were used. Selected companies can serve as a representative research sample and therefore the obtained results for the observed sector can be generalized. The research period was from 01.01.2008. to 31.12.2014. Internal factors that were the subject of research are company-specific factors - size, financial indebtedness coefficients, profitability indicators, market ratio indicators, book value per share. Data for internal factors were obtained as rational numbers using the items from the balance sheet and the profit and loss account of the observed companies.

In accordance with previous studies examining the relationship between stock prices and internal factors of the company, a table with the variables used in the regression analysis was formed. The following table gives an overview of the company performances that were analyzed as potential determinants of stock prices. 
Milošević-Avdalović S.: The Impact of Firm Specific Factors on the Stock Prices...

Table 1. Definition of variables used in regression analysis

\begin{tabular}{|c|c|c|c|}
\hline Variables: & Symbol & Definition & $\begin{array}{c}\text { Expected } \\
\text { impact }\end{array}$ \\
\hline \multicolumn{4}{|c|}{ Independent variables or predictors } \\
\hline Company size & SIZE & $\begin{array}{l}\text { Market price of shares } x \text { number of issued } \\
\text { ordinary shares (LnMaCap) }\end{array}$ & + \\
\hline Return on equity & ROE & Net profit/ Total equity & + \\
\hline Return on assets & ROA & Net profit/ Total assets & + \\
\hline Earnings per share & EPS & Net profit/ number of issued ordinary share & + \\
\hline $\mathrm{P} / \mathrm{E}$ ratio & $\mathrm{P} / \mathrm{E}$ & Market price of shares/Earning per share & + \\
\hline Book value & BV & $\begin{array}{c}\text { Share capital/ number of issued ordinary } \\
\text { shares }\end{array}$ & + \\
\hline Leverage & LEV & $\begin{array}{l}\text { Total liabilities (sources of borrowed capital)/ } \\
\text { Total assets }\end{array}$ & - \\
\hline Trust rate & TR & Total capital/Total liabilities & + \\
\hline \multicolumn{4}{|c|}{ Dependent variable } \\
\hline Market price of shares & MPS & $\begin{array}{l}\text { Closing price of shares } 31.12 \text {. of the observed } \\
\text { year }\end{array}$ & \\
\hline
\end{tabular}

Source: Author

In the column titled Impact on the stock price a positive or negative effect of the observed independent variables (predictors) on the dependent variable is assumed. The basis for selected independent indicators were the previously conducted research by numerous authors on this topic both in developed capital markets and in emerging capital markets.

Table 2. Descriptive statistics of data

\begin{tabular}{|l|r|r|r|r|}
\hline & N & \multicolumn{1}{|c|}{ Minimum } & Maximum & \multicolumn{1}{c|}{ Mean } \\
\hline MPS & 129 & 25.00 & 25754.00 & 5549.4031 \\
\hline SIZE & 129 & 12468050.00 & 37016321156.00 & 4705069258.5736 \\
\hline ROE & 129 & -3.38 & .78 & .0007 \\
\hline ROA & 129 & -.79 & .50 & .0181 \\
\hline EPS & 129 & -5447.19 & 8396.78 & 400.7963 \\
\hline P/E & 129 & -50.91 & 9837.31 & 115.5481 \\
\hline BV & 129 & 342.31 & 38715.81 & 10048.7175 \\
\hline LEV & 129 & .00 & .90 & .5505 \\
\hline TR & 129 & .11 & 459.02 & 12.4574 \\
\hline
\end{tabular}

Source: Author

Descriptive statistics (Table 2) indicate the maximum, minimum and mean values of the observed variables. It is worth mentioning that with $\mathrm{P} / \mathrm{E}$ ratio there is a wide variation between minimum and maximum values. This points to the fact that investors are willing to pay a high premium for well performing businesses. The analysis of the earnings per share (EPS) statistics indicates 
Milošević-Avdalović S.: The Impact of Firm Specific Factors on the Stock Prices...

that the median value is not a convincing figure for investors and for this reason a large number of companies, both small and large, liquid, less liquid and illiquid in was included the analysis. Also, low average value of earnings per variable in the Financial and Insurance Activities Sector can be attributed to the effect of the global financial crisis.

\subsection{Methodology}

\subsubsection{Regression analysis}

Multiple regression represents a family of techniques by which the relationship between dependent variables and multiple independent variables or predictors can be investigated. There are solid theoretical and empirical reasons for applying this analysis.



Where are:

MPS $=$ market stock price (dependent variable)

$\beta 0=$ Coefficient of Intercept (Constant)

$\beta 1-\beta 8=$ Coefficients of Slop

$\mathrm{i}, \mathrm{t}$ - company (i) in time (t)

$\mathrm{e}=$ error term

Preliminary analyses have shown that the assumptions of normality, homogeneity, linearity and multicollinearity are not distorted.

\subsubsection{Cluster analysis}

Cluster analysis is a statistical technique for determining relatively homogeneous groups of observed units (companies). Grouping of the companies according to similarities was done according to the fundamental determinants of the prices of stocks, obtained on the basis of regression analysis. This division should have the following characteristics, homogeneity within groups and heterogeneity between groups, or clusters. Since the period of analysis and observation was from 2008 to 2014, for the needs of the cluster analysis, the mean values of the observed variables of the company were used. Large ranges in the values of the observed variables indicate the need for grouping the company according to the similarities in performance, in order to obtain homogeneous subgroups that are characterized by similar performances.

Such segmentation can be significant for investors both in terms of diversification of their own portfolio, but also for the companies themselves in order to recognize their position on the market. The transformation (editing) of 
Milošević-Avdalović S.: The Impact of Firm Specific Factors on the Stock Prices...

data into a standardized form was made, transformation ranging from -1 to +1 . Transformation is a normalization that aims to enable the use of input data. The Euclidean distance was used for distance measurements. In the formula, the standard Euclidean distance of two objects $X$ and $Y$ is calculated as the square root of the sum of the square value difference for each variable $\mathrm{Xi}$, Yi respectively. The smaller the Euclidean distance is, the greater the similarity of the observed features - the stock price of the companies is.

Distance $(\mathrm{X}, \mathrm{Y})=\sqrt{\sum\left(X_{i}-Y_{i}\right)^{2}}$

Before conducting a cluster analysis, it is necessary to determine the level of correlation between the observed variables.

\section{Results and discussion}

Using non-stationary series in a regression model can create the effect of the so-called "spurious regression" and indicate the wrong, biased, conclusion about the significance of the model. It is therefore necessary to check that the observed series meet the requirement of stationarity. The Schwarz criterion was used to determine the optimal number of lags of the auto regression model.

Table 3. Unit root test

\begin{tabular}{|l|c|c|}
\hline & ADF test & PP test \\
& Augmented Dickey-Fuller test statistic & Phillips-Perron test statistic \\
\hline MPS & -9.272356 & -9.108108 \\
& $(0.0000)$ & $(0.0000)$ \\
\hline SIZE & -7.921318 & -13.93930 \\
& $(0.000)$ & $(0.0000)$ \\
\hline ROE & -11.30865 & -11.30953 \\
& $(0.0000)$ & $(0.0000)$ \\
\hline ROA & -10.95305 & -10.96600 \\
& $(0.0000)$ & $(0.0000)$ \\
\hline EPS & -13.12494 & -13.04659 \\
& $(0.0000)$ & $(0.0000)$ \\
\hline P/E & -11.39622 & -11.39663 \\
& $(0.0000)$ & $(0.0000)$ \\
\hline BV & -8.196618 & -17.61809 \\
& $(0.0000)$ & $(0.0000)$ \\
\hline LEV & -12.15986 & -8.807284 \\
& $(0.0000)$ & $(0.0000)$ \\
\hline TR & -11.73530 & -11.87305 \\
& $(0.0000)$ & $(0.0000)$ \\
\hline Note: & \multicolumn{2}{|c|}{}
\end{tabular}

Test critical values for ADF test : $1 \%$ level $-3.484198,5 \%$ level $-2.885051,10 \%$ level $-2.5793865 \%$ Test critical values for PP test : $1 \%$ level-3.482035, 5\% level $-2.884109,10 \%$ level $-2.578884 \%$

Source: Author 
Milošević-Avdalović S.: The Impact of Firm Specific Factors on the Stock Prices...

In Table 3, the results of the ADF test and PP test show that all tested variables are stationary at level I (0) with a level of significance of $1 \%$, which is the basis for the use of multiple regression analysis.

Table 4. Multicollinearity statistics test

\begin{tabular}{|l|r|r|}
\hline & Tolerance & \multicolumn{1}{|c|}{ VIF } \\
\hline SIZE & .721 & 1.388 \\
\hline ROE & .423 & 2.366 \\
\hline ROA & .396 & 2.522 \\
\hline EPS & .791 & 1.265 \\
\hline P/E & .987 & 1.014 \\
\hline BV & .818 & 1.223 \\
\hline LEV & .618 & 1.618 \\
\hline TR & .741 & 1.349 \\
\hline \multicolumn{2}{|r|}{} & \multicolumn{2}{|c|}{ Mean VIF: 1.5931} \\
\hline
\end{tabular}

Source: Author

The mean value of VIF is 1.5931, less than 10, which confirms the absence of any multicollinearity, and the VIF test for individual variables does not exceed the maximum value of 10 , and therefore there is no need to eliminate certain variables from the regression analysis (Table 4).

Table 5. Company Performances with Fundamental Impact on Stock Prices in the period from 2008.-2014.(Stock of company on K - Financial and Insurance Activities Sector)

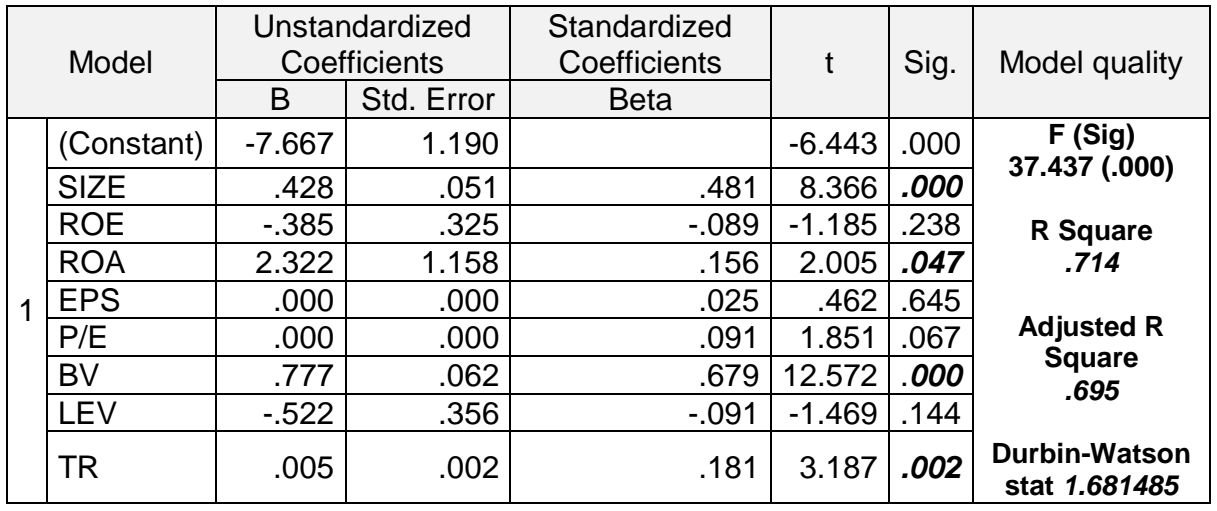

Source: Author

Based on the results of the panel analysis in Table 5, it can be concluded that the variable size, book value per share and trust rate are statistically significant at the level of significance of $99 \%$, while the variable return on 
Milošević-Avdalović S.: The Impact of Firm Specific Factors on the Stock Prices...

assets is statistically significant at the level of significance of $95 \%$. Adjusted R Square is 0.695 , or $69.5 \%$ of variations in the market price of stocks can be explained by variables included in this study. The $p$ value for the $F$ test is .000 , and shows a value of $1 \%$ indicating that the model is acceptable. The standardized variation coefficient - beta indicates the number of standard deviations for which stock prices will change to predict changes for one standard deviation unit (deviation). The variation coefficient ( $p$ value) explains the positive direction of variability for book value, size (market capitalization), trust rate, return on assets and amounts to .679 (.000), .481 (.000), .181 (.002) and .156 (.047), respectively. The results indicate that the market value of one share is affected by the increase in book value, size, trust rate and return on assets. This indicates that the trend of growth of these variables will automatically lead to an increase in the market price of shares and that investors show a tendency for these stocks. Size (measured by market capitalization) is found to be one of the most significant internal determinant of the stock price movements as the previous literature has reported (Duy and Phuoc, 2016; Gan et al. 2013).

In order to create a clearer picture of key determinants of stock prices, the following table presents the results of multiple regression analysis results by years, as well as the results of the residual diagnostic tests.

Table 6. Regression analysis of stock prices of companies in the Financial and Insurance Activities Sector by year for the period from 2008 to 2014

\begin{tabular}{|c|c|c|c|c|c|c|}
\hline Year & $\begin{array}{c}\mathrm{R} \\
\text { squared }\end{array}$ & $\begin{array}{l}\text { F-value (p- } \\
\text { value) }\end{array}$ & D-W stat & $\begin{array}{c}\text { LM } \\
\text { corrleation }\end{array}$ & $\begin{array}{c}\text { BPG } \\
\text { heterosk. }\end{array}$ & $\begin{array}{l}\text { Key determinants } \\
\text { of the stock price }\end{array}$ \\
\hline 2008 & $78.27 \%$ & $\begin{array}{c}4.052896 \\
(0.025928)\end{array}$ & 1.810240 & $\begin{array}{l}0.3162 \\
0.0802\end{array}$ & $\begin{array}{l}0.6495 \\
0.5129\end{array}$ & BV, TR \\
\hline 2009 & $80.97 \%$ & $\begin{array}{l}4.786564 \\
0.015443\end{array}$ & 2.419720 & $\begin{array}{l}0.0357 \\
0.0040\end{array}$ & $\begin{array}{l}0.8427 \\
0.7160\end{array}$ & $B V, P / E$ \\
\hline 2010 & $72.52 \%$ & $\begin{array}{l}3.299368 \\
0.040507\end{array}$ & 1.359568 & $\begin{array}{l}0.4925 \\
0.2140\end{array}$ & $\begin{array}{l}0.5062 \\
0.4036\end{array}$ & SIZE, BV \\
\hline 2011 & $87.13 \%$ & $\begin{array}{l}8.463446 \\
0.001408\end{array}$ & 2.072804 & $\begin{array}{l}0.8723 \\
0.7269\end{array}$ & $\begin{array}{l}0.1365 \\
0.1563\end{array}$ & EPS, P/E, BV, TR \\
\hline 2012 & $81.87 \%$ & $\begin{array}{l}5.642746 \\
0.006738\end{array}$ & 2.046622 & $\begin{array}{l}0.8914 \\
0.7641\end{array}$ & $\begin{array}{l}0.10504 \\
0.7354\end{array}$ & SIZE, BV \\
\hline 2013 & $89.61 \%$ & $\begin{array}{l}9.698095 \\
0.001289\end{array}$ & 1.899598 & $\begin{array}{l}0.7313 \\
0.4632\end{array}$ & $\begin{array}{l}0.3651 \\
0.3001\end{array}$ & SIZE, BV \\
\hline 2014 & $92.06 \%$ & $\begin{array}{l}13.04679 \\
0.000409\end{array}$ & 1.363367 & $\begin{array}{l}0.7211 \\
0.4482\end{array}$ & $\begin{array}{l}0.7192 \\
0.5780\end{array}$ & $\begin{array}{c}\text { SIZE, ROA, ROE, } \\
\text { BV }\end{array}$ \\
\hline
\end{tabular}

Source: Author

As presented in the table above the key determinant of the stock prices, in the sector Financial and insurance activities for all observed years are size (+) and book value per share (+). Apart from the above-mentioned two determinants of stock prices, trust rate, $\mathrm{P} / \mathrm{E}$ ratio, return on equity and return 
Milošević-Avdalović S.: The Impact of Firm Specific Factors on the Stock Prices...

on assets have a significant positive impact, which indicates that investors prefer companies that are earning more and investing funds in profitable projects. Earnings per share (EPS) indicate a statistically significant positive impact on the stock price in post-crisis period, in 2011. EPS is found to be the significant internal determinant of the stock price movements as the previous literature has reported (Pushpa Bhatt and Sumangala, 2012.). It is concluded that the model does not have a serial correlation (LM test) which is desirable for the validity of the model. The model has a high value of the coefficient of determination (R2) and at the same time the F statistics is significant. The heteroskedasticity test indicates the stability of variance (based on F statistics and Breusch-Pagan-Godfrey). Durbin-Watson test indicates the absence of a serial autocorrelation residual. The residual diagnostic tests indicate that the multiple regression analysis model is acceptable over the years.

The first step in the cluster analysis is the implementation of the correlation of the explanatory variables, i.e. the separated statistically significant accounting performances.

Table 7. Correlation of key variables of cluster analysis - Financial and Insurance Activities Sector

\begin{tabular}{|l|l|r|r|r|r|}
\hline \multicolumn{2}{|c|}{} & \multicolumn{1}{c|}{ ROA } & \multicolumn{1}{c|}{ BV } & SIZE & \multicolumn{1}{c|}{ TR } \\
\hline \multirow{3}{*}{ ROA } & Pearson Correlation & 1 & .090 & .064 & .230 \\
\cline { 2 - 6 } & Sig. (2-tailed) & & .713 & .795 & .343 \\
\cline { 2 - 6 } & $\mathrm{N}$ & 19 & 19 & 19 & 19 \\
\hline \multirow{3}{*}{ BV } & Pearson Correlation & .090 & 1 & .028 & .131 \\
\cline { 2 - 6 } & Sig. (2-tailed) & .713 & & .909 & .594 \\
\cline { 2 - 6 } & $\mathrm{N}$ & .064 & .028 & 19 & 19 \\
\hline \multirow{3}{*}{ SIZE } & Pearson Correlation & .795 & .909 & 1 & -.456 \\
\cline { 2 - 6 } & Sig. (2-tailed) & 19 & 19 & 19 & .050 \\
\cline { 2 - 6 } & $\mathrm{N}$ & .230 & .131 & -.456 & 19 \\
\hline \multirow{3}{*}{ TR } & Pearson Correlation & .343 & .594 & .050 & 1 \\
\cline { 2 - 6 } & Sig. (2-tailed) & 19 & 19 & 19 & 19 \\
\cline { 2 - 6 } & $\mathrm{N}$ & & & &
\end{tabular}

Source: Author

In the analysis of Pearson's correlation (Table 7) it was noticeable that the level of correlation between the two variables did not exceed the threshold of 0.90 , and therefore all the variables could be included in further analysis. Size (market capitalization), book value per share, return on assets and trust rate were chosen as the key performances for the cluster analysis. The next dendrogram provides a visual insight into cluster formation. 
Milošević-Avdalović S.: The Impact of Firm Specific Factors on the Stock Prices...

Figure 1. Dendrogram of companies belonging to the sector K - Financial and Insurance Activities

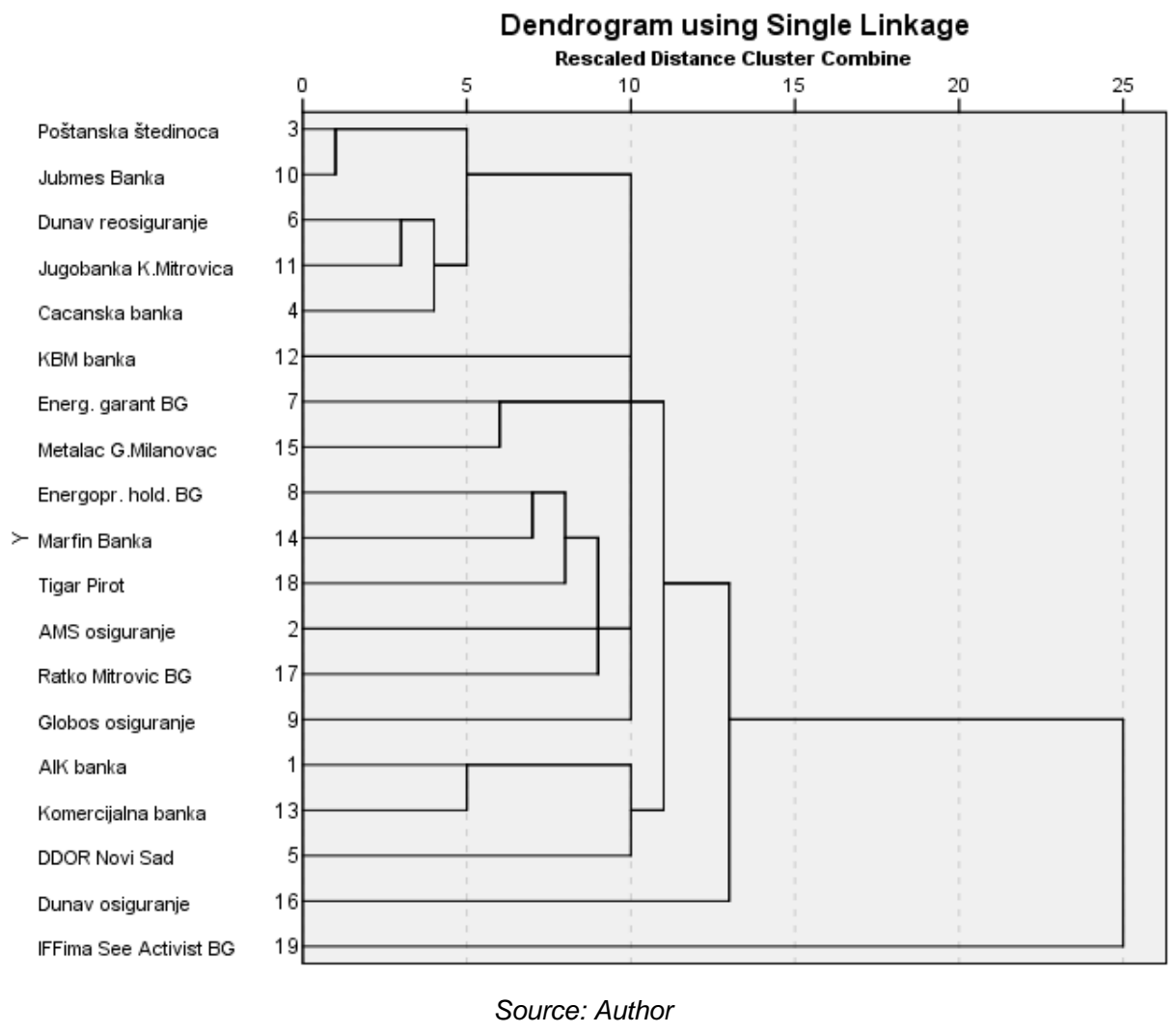

On a dendrogram, Fig.1, objects (companies) are divided on a vertical axis, while the horizontal axis indicates the distance between the connecting objects. The hierarchical cluster analysis points to the similarity of most of the observed companies, while the differences increase with the growth of the company.

Based on descriptive statistics and three clusters (set up in advance), it is noticeable that sixteen companies make up a cluster 1 , two companies represent cluster 2 and one company is in a cluster 3 . Analyzing the mean and minimum values of the observed variables per clusters, significant differences can be noticed (Table 8). An additional statistical test (ANOVA) should answer the question of whether there is a statistically significant difference in performance between the three clusters. The results of the test are presented in the following table. 
Milošević-Avdalović S.: The Impact of Firm Specific Factors on the Stock Prices...

Table 8. Descriptive statistics for variables included in cluster analysis Financial and Insurance Activities Sector

\begin{tabular}{|c|c|c|c|c|c|c|}
\hline \multicolumn{2}{|c|}{ Single Linkage } & $\mathrm{N}$ & Minimum & Maximum & Mean & Std. Deviation \\
\hline & $\mathrm{ROA}$ & 16 & -.11 & .06 & .0031 & .04175 \\
\hline & TR & 16 & .19 & 7.37 & 1.2388 & 1.84048 \\
\hline 1 & SIZE & 16 & 18.95 & 23.68 & 21.5036 & 1.55499 \\
\hline & BV & 16 & 6.12 & 10.53 & 8.4731 & 1.48021 \\
\hline & Valid N (listwise) & 16 & & & & \\
\hline \multirow{5}{*}{2} & $\mathrm{ROA}$ & 2 & .09 & .11 & .1000 & .01414 \\
\hline & TR & 2 & 2.99 & 5.43 & 4.2100 & 1.72534 \\
\hline & SIZE & 2 & 20.06 & 21.46 & 20.7610 & .99278 \\
\hline & BV & 2 & 7.88 & 8.45 & 8.1650 & .40305 \\
\hline & Valid N (listwise) & 2 & & & & \\
\hline \multirow{5}{*}{3} & $\mathrm{ROA}$ & 1 & .06 & .06 & .0600 & \\
\hline & TR & 1 & 202.58 & 202.58 & 202.5800 & \\
\hline & SIZE & 1 & 18.18 & 18.18 & 18.1790 & \\
\hline & BV & 1 & 9.31 & 9.31 & 9.3100 & \\
\hline & Valid N (listwise) & 1 & & & & \\
\hline
\end{tabular}

Source: Author

Based on the obtained results in Table 9, it can be noticed that the companies ZIF Fima SEE Activist a.d., Beograd (cluster III) and Metalac a.d., Gornji Milanovac and Energoprojekt garant a.d., Novi Beograd (cluster II) significantly differ from the clusters of other enterprises (cluster I) by return on assets, as well as by trust rate, while the indicator of book value per share and size does not indicate a statistically significant difference between clusters.

Table 9. ANOVA - Statistical significance of differences in observed performances among clusters for the model Financial and insurance activities

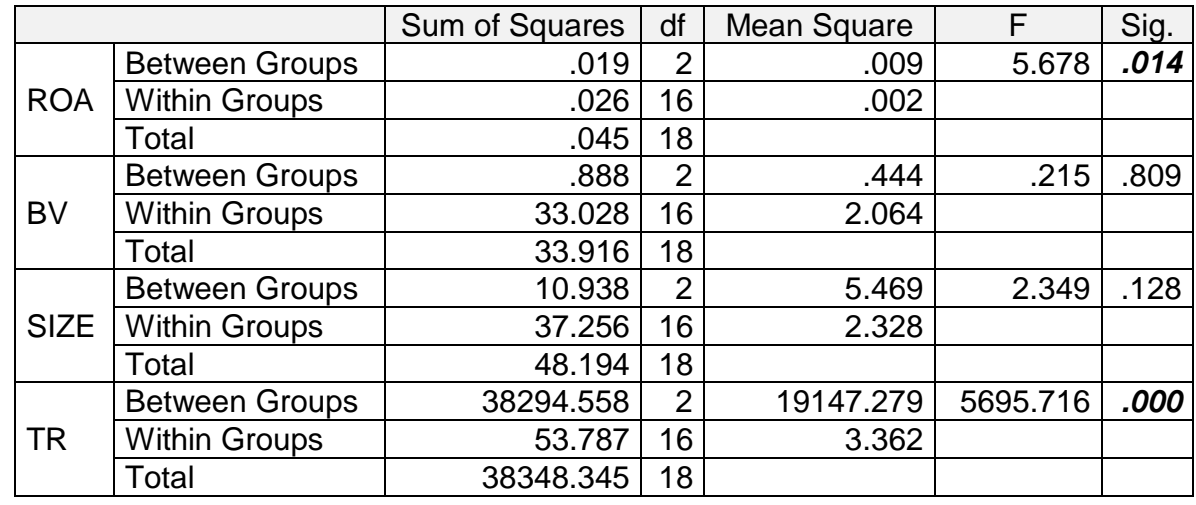

Source: Author 
Milošević-Avdalović S.: The Impact of Firm Specific Factors on the Stock Prices..

\section{Conclusions and recommendations}

The research was conducted in order to test the influence of business operations on the prices of the shares of the observed companies in the period from 2008 to 2014. Based on empirical analysis, variables such as size (market capitalization), book value per share, returns on assets and trust rate have a positive impact on the price of stocks in the Financial and Insurance Activities Sector. It is recommended that the directors of the firms listed on the Belgrade Stock Exchange introduce policies which would have a positive impact on their financial performances to significantly influence their stock prices positively.

The findings of this study are similar to the results of some variables utilized by Rjoub, Civcir and Resatoglu (2017), Mishra \& Dhole (2015), Chughtai, Azeem and Ali (2014), Sharif, Purohit and Pillai (2015), Kodithuwakku (2016), Tudor (2010), ulHaq and Rashid (2014), Menaje (2012) and Wang, Fu \& Luo (2013).

The results of this study confirm the usefulness of the analysis of performance of specific variables of companies and can be used to help investors in making rational decisions with regard to their stock portfolio.

However, this research has certain limitations. In case of the selected companies from the Financial and Insurance Activities Sector, the research only takes into consideration companies' specific factors and ignores impact of macro-economic factors on stock price. Also, the research was conducted on a set of data obtained from the financial statements. Therefore, the reliability and accuracy of these data will affect the applicability of the research results.

Future research should take into account macro and micro factors as well as companies from other sectors to define factors influencing the stock price.

\section{References}

Anwaar, M. (2016). Impact of Firms Performance on Stock Returns (Evidence from Listed Companies of FTSE-100 Index London, UK). Global Journal of Management And Business Research, 16(1), 31-39.

Aveh, F.K., Awunyo-Vitor , D.\& McMillan, D.(2017). Firm-specific determinants of stock prices in an emerging capital market: Evidence from Ghana Stock Exchange. Cogent Economics \& Finance,5(1), doi: 10.1080/23322039.2017.1339385

Chughtai, A. R., Azeem, A., \& Ali, S. (2014). Determining the Impact of Dividends, Earnings, Invested Capital and Retained Earnings on Stock Prices in Pakistan: An Empirical Study. International Journal of Financial Management, 4(1),74-81. 
Milošević-Avdalović S.: The Impact of Firm Specific Factors on the Stock Prices...

Duy, N. T., \& Phuoc, N. P. H. (2016). The Relationship between Firm Sizes and Stock Returns of Service Sector in Ho Chi Minh City Stock Exchange. Review of European Studies, 8(4), 210-219. http://dx.doi.org/10.5539/res.v8n4p210

Gan, C., Hu, B., Li, Z., \& Liu, Y.(2013). An empirical cross-section analysis of stock returns on the Chinese A-share stock market. Investment Management and Financial Innovations, 1, 127-136.

Issah, O., \& Ngmenipuo, I. M. (2015). An empirical study of the relationship between profitability ratios and market share price of publicly traded banking financial institutions in Ghana. International Journal of Economics, Commerce and Management, 3(12), 27-42.

Kodithuwakku, S.(2016). Impact of Firm Specific Factors on the Stock Prices: A Case Study on Listed Manufacturing Companies in Colombo Stock Exchange, International Journal for Research in Business, Management and Accounting, 2 (3), 67-76.

Kothari, S. P. (2001). Capital markets research in accounting. Journal of Accounting and Economics, 31, 105-231. https://doi.org/10.1016/S0165-4101(01)00030-1

Menaje, P. M. (2012). Impact of selected financial variables on share price of publicly listed firms in the Philippines.American international journal of Contemporary Research, 2(9), 98-104.

Mirza, N., Rahat, B.,\& Reddy, K.(2016). Financial leverage and stock returns: evidence from an emerging economy. Economic ResearchEkonomskalstraživanja,29(1),85-100. doi: 10.1080/1331677X.2016.1160792

Mishra, S., \& Dhole, S. (2015). Stock Price Comovement: Evidence from India. Emerging Markets Finance and Trade, 51(5), 893903.doi:10.1080/1540496X.2015.1061381

Pushpa Bhatt, P., \& Sumangala, J. K. (2012). Impact of Earnings per share on Market Value of an equity share: An Empirical study in Indian Capital Market. Journal of Finance, Accounting \& Management, 3(2), 1-14.

Rjoub, H., Civcir, I., \& Resatoglu, N. G. (2017). Micro and Macroeconomic Determinants of Stock Prices: The Case of Turkish Banking Sector. Journal for Economic Forecasting, XX (1), 150-166.

Sharif, T., Purohit, H., \& Pillai, R. (2015). Analysis of Factors Affecting Share Prices: The Case of Bahrain Stock Exchange, International Journal of Economics and Finance, 7, (3), 207-216. http://dx.doi.org/10.5539/ijef.v7n3p207

Tudor, C. (2010). Firm-specific factors as predictors of future returns for Romanian common stocks:empirical evidence. Recent Researches in Business Administration, Finance and Product Management, ICFA 10, 73-78.

ul Haq, I., \& Rashid, K. (2014). Stock Market Efficiency and Size of the Firm: Empirical Evidence from Pakistan. Oeconomics of Knowledge, 6(1), 10-31.

Wang, J., Fu, G., \& Luo, C. (2013). Accounting information and stock price reaction of listed companies-empirical evidence from 60 listed companies in Shanghai Stock Exchange. Journal of Business \& Management, 2(2), 11-21. 